\title{
On the unusual characteristics of the diamonds from Letšeng-la- Terae kimberlites, Lesotho
}

\author{
Debbie C. Bowen', Ray D. Ferraris ${ }^{1}$, Claire E. Palmer ${ }^{2,3}$ and John D. Ward ${ }^{3}$ \\ ${ }^{1}$ Letšeng Diamonds (Pty) Ltd, Maseru, Lesotho \\ ${ }^{2}$ CSIR Natural Resources and the Environment, Johannesburg, South Africa \\ ${ }^{3}$ Gem Diamond Technical Services (Pty) Ltd, Johannesburg, South Africa
}

\begin{abstract}
Introduction
The Letšeng-la-Terae kimberlites, discovered in December 1957, are situated some 3,100 metres above sea level in the Maloti Mountains of the Kingdom of Lesotho in southern Africa (Figure 1). The principal economic bodies are two Late Cretaceous (c. $91 \mathrm{Ma}$ ), low-grade (1 to 3 carats per hundred ton, cpht), Group 1 kimberlite pipes that host high-value diamonds that fetch in excess of US $\$ 2,500 /$ carat $(\$ / \mathrm{ct})$. The larger kimberlite is referred to as the Main Pipe (17.2 ha) and the smaller body is called the Satellite Pipe (5.2 ha).
\end{abstract}

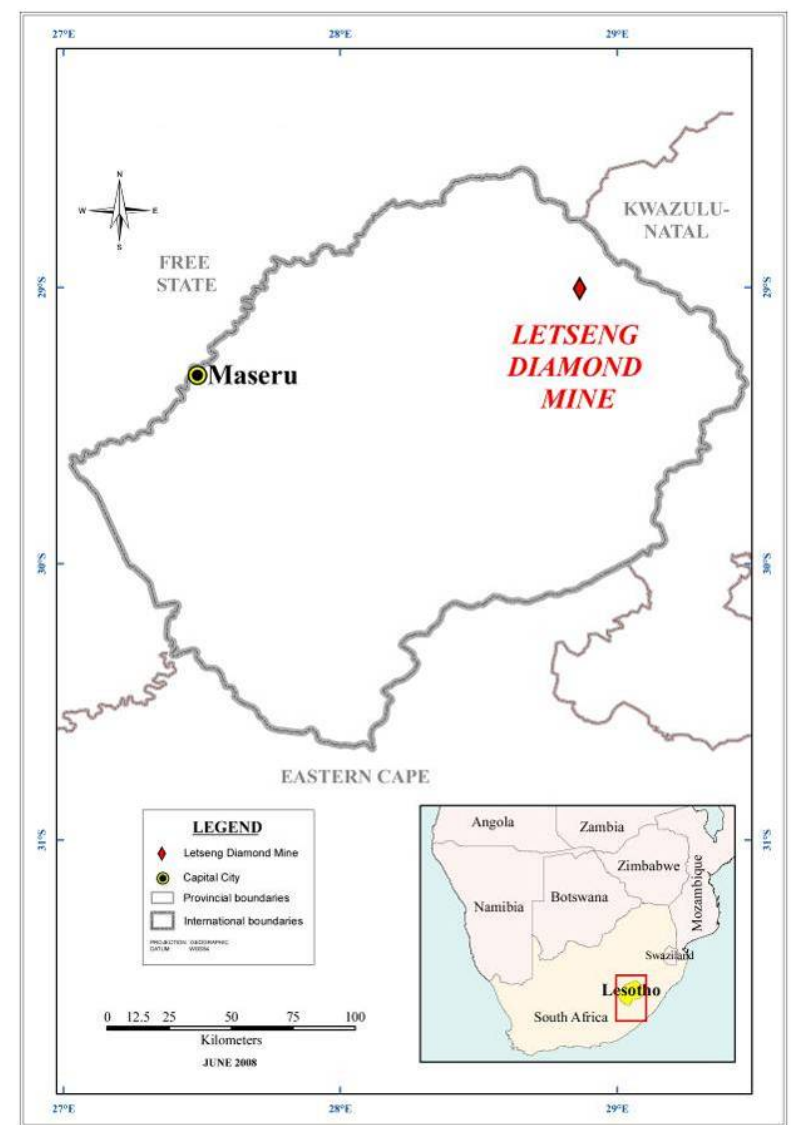

Figure 1. Locality map of the Letšeng Diamond Mine, Lesotho

The Letšeng pipes, and their associated eluvial and proximal alluvial deposits, are renowned for yielding large, +100 carat (ct) diamonds - the majority of which have been ' $\mathrm{D}$ ' colour, potentially flawless stones. To date, at least twenty-six +100 ct diamonds have been recovered - the two largest being the $601 \mathrm{ct}$ Lesotho Brown found in 1968 and the 603 ct Lesotho Promise in 2006. Diamonds were recovered initially by artisanal mining in the 1960 s, yielding c. 63,000 cts. Subsequent formal mining between 1977 and 1982 produced c. 273,000 cts (Whitelock et al., 2004). Some 21 years later, in 2003, Letšeng Diamonds (Pty) Ltd recommenced formal mining and had recovered c. 241,000 cts by the end of May 2008. From recent detailed production records and our ongoing regular diamond studies, we highlight the following unusual characteristics, viz., quality, average stone size, shape, colour and Type IIa content, of the Letšeng diamonds that make these two low grade kimberlite pipes an economic mine.

\section{Diamond Quality}

The quality of the diamonds recovered from the Letšeng pipes averages $75 \%$ gem, well above the global average for kimberlites (Figure 2). The bulk of the non-gem stones comprise mainly clivage and dark browns $(15 \%-20 \%)$ with rejections and boart running at $5 \%-11 \%$.

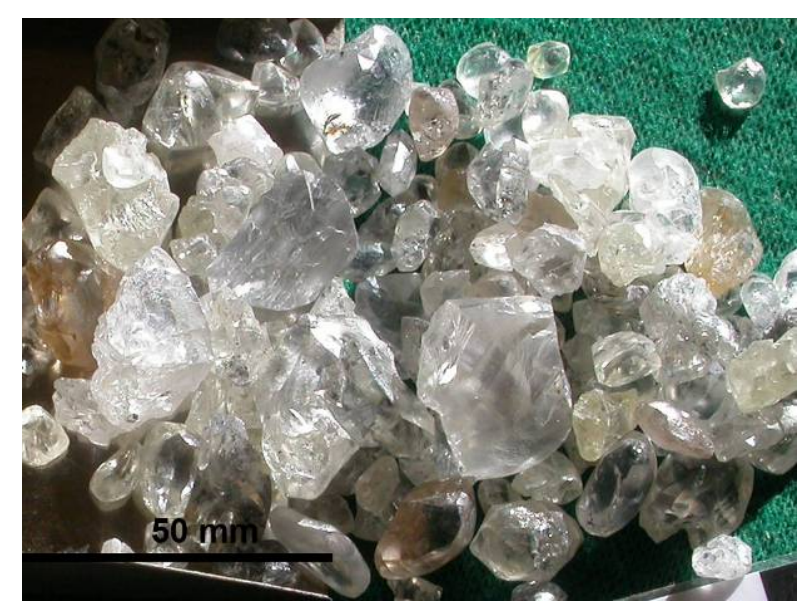

Figure 2. Example of gem quality diamonds recovered at Letšeng

\section{Diamond Size}

Based on our c. 200,000 cts study from both pipes, the average stone size for Letšeng is 0.98 carats per stone (cts/stn). This is approximately an order of magnitude greater than the average stone size for the majority of the world's kimberlites and is more comparable to 
some large-stone, alluvial diamond placers e.g. Lower Orange River. Size frequency analyses (using diamond sieve class sizes) show remarkable similarity between the Main and the Satellite Pipes (Figure 3). Interestingly, our results indicate that the occurrence of a $+1,000$ ct diamond is not impossible $(0.15 \%$ probability).

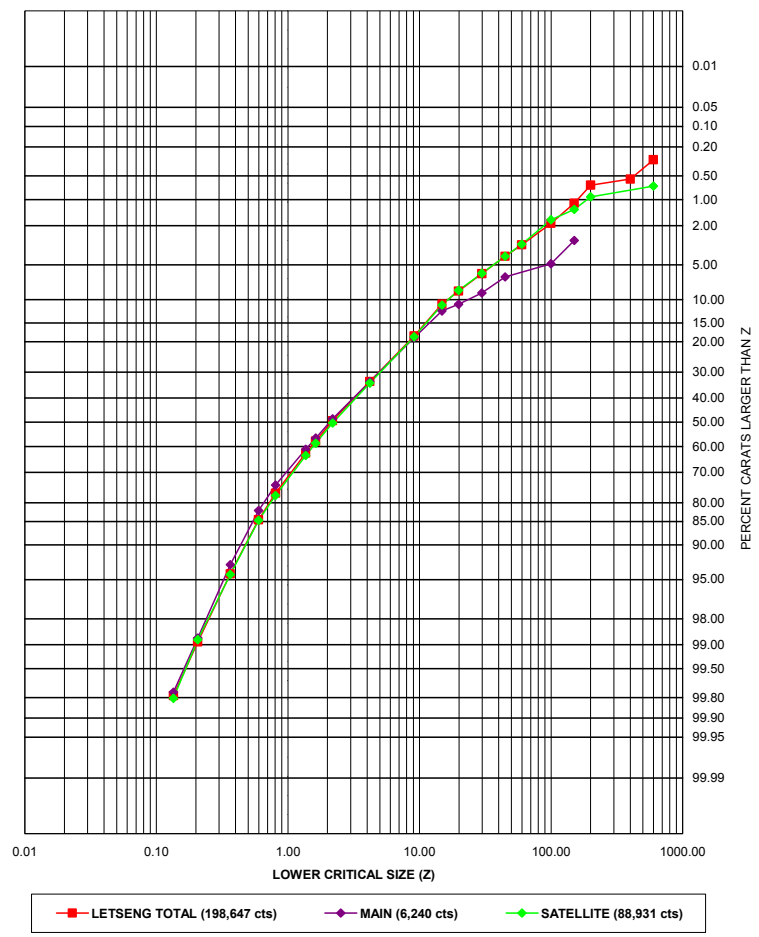

Figure 3. Size frequency distribution of Main Pipe, Satellite Pipe and Letšeng total production (March 2004 to May 2008)

\section{Diamond Shape}

Whilst the dodecahedral form is the dominant diamond shape at Letšeng (Main Pipe 67\%: Satellite Pipe 87\%), the classic rounded shape is uncommon $(<10 \%)$, with the remainder $(>90 \%)$ being irregular and elongated (Figure 4). Likewise the rare presence of the octahedral form $(<1 \%)$ and, to date, the absence of the cubic form, is deemed unusual in a general kimberlite diamond population. Macles and twins (12\% for Satellite Pipe and $32 \%$ for Main Pipe) and minor broken forms make up the balance of the shapes in the Letšeng population.

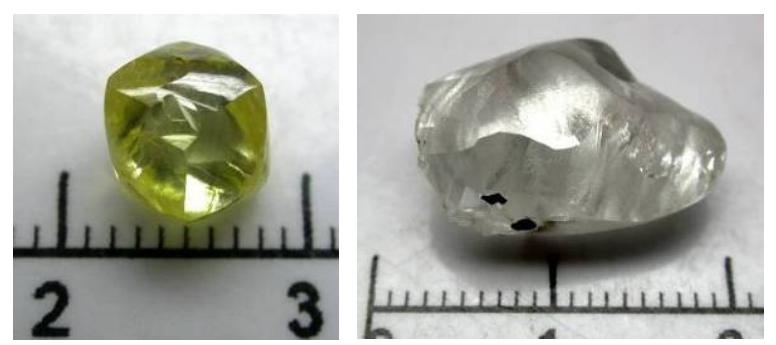

Figure 4. Rounded dodecahedral form on the left and irregular dodecahedron on the right
The large average stone size and the predominant irregular dodecahedral form exhibited by the Letšeng diamonds are attributed to a high degree of resorption (Robinson, 1979). We speculate that extreme resorption conditions were responsible for the lack of octahedral forms and the dissolution of the finergrained diamond suite. Significantly, our petrographic studies provide supporting evidence for strong resorption of a number of other mantle-derived minerals, notably olivine and garnet xenocrysts, as well as evidence for fractionation of the kimberlite melt (Figure 5). This fractionation process also produced coarse olivine phenocrysts, spinel, perovskite and zircon (Figure 6). Therefore it is during this period of kimberlite melt fractionation, that the bulk of the diamond resorption is likely to have occurred.

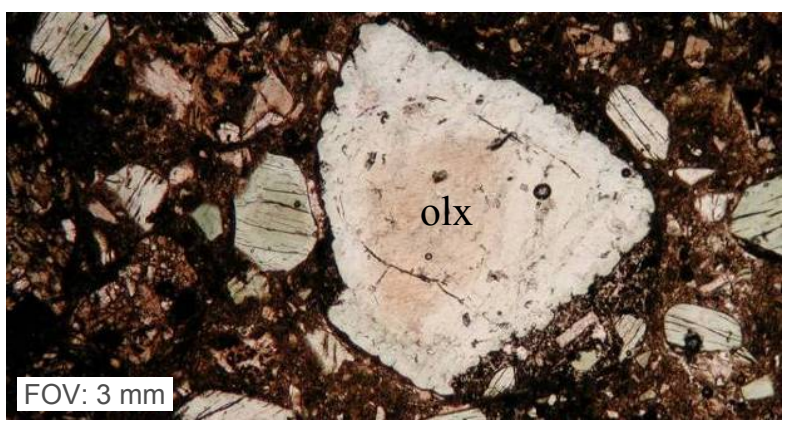

Figure 5. Photomicrograph showing an olivine xenocryst (olx) that exhibits a saw-tooth texture along its edges, formed as a result of resorption

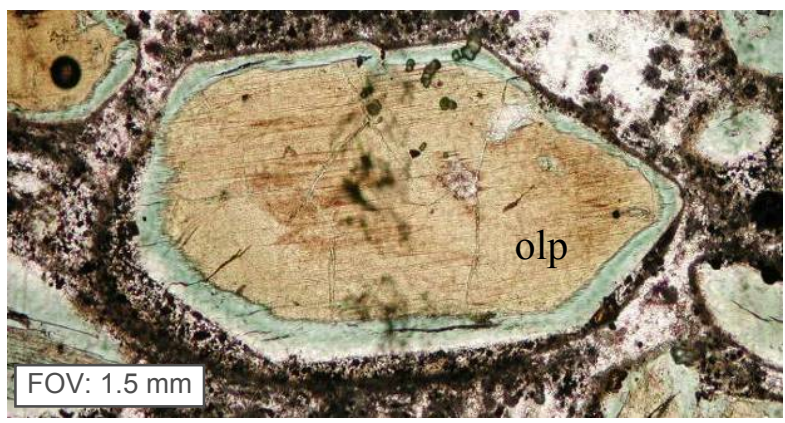

Figure 6. Photomicrograph of an olivine phenocryst (olp), an example of a coarse kimberlite mineral

\section{Diamond Colour}

Although earlier work suggested a dominance of white colours in both pipes (Robinson, 1979), our results, which are based on a larger population, indicate that brown stones are prevalent in the Main Pipe (c. 33\%) and that light yellow is the prevailing colour in the Satellite Pipe (c. 41\%; Table 1). Nonetheless, we still found an unusually high percentage (c. $32 \%$ ) of white stones in both pipes which are economically welcome.

Table 1. Colour distribution of diamonds in the Main and Satellite Pipes, Letšeng $(\mathrm{n}=$ stones $)$

\begin{tabular}{|c|c|c|}
\hline Main Pipe $(\mathrm{n}=22068)$ & Diamond Colour & Satellite Pipe $(\mathrm{n}=16185)$ \\
\hline $32.46 \%$ & WHITE & $32.75 \%$ \\
\hline $29.12 \%$ & YELLOW & $41.01 \%$ \\
\hline $33.43 \%$ & BROWN & $15.47 \%$ \\
\hline $4.75 \%$ & GREY/BOART & $10.68 \%$ \\
\hline $0.24 \%$ & FANCY & $0.09 \%$ \\
\hline
\end{tabular}




\section{Type IIa Diamonds}

The most unusual, and the most economically important, characteristic of the Letšeng diamonds is the abundance of Type IIa, nitrogen-free, 'D' colour, gem quality stones. Earlier studies, which were restricted to the smaller size fractions, indicated that Type IIa stones comprised some $12-15 \%$ of the Letšeng diamond population (McDade and Harris, 1999; McKenna, 2004). However, with access to the full size range of diamonds produced at Letšeng since 2003, our studies show that Type IIa diamonds are a major component of the larger size fractions, in particular those sizes greater than +10.8 cts.

Overall, the Main Pipe diamond population has c. 19\% and the Satellite Pipe c. $25 \%$ Type IIa stones. In the largest fraction, the Type IIa stones in the Main Pipe comprise c. $32 \%$ of the +10.8 ct diamonds whereas in the Satellite Pipe this runs at c. $51 \%$ (Table 2). Significantly, of the twenty-four +100 ct diamonds recovered between November 2003 and May 2008, nineteen (c. 79\%) were Type IIa stones with eighteen of these (c. 75\%) white, ' $D$ ' colour, gem quality stones and the remaining one stone a top light brown colour. The balance of the +100 ct diamonds comprised three Type I stones (c. 13\%; 2 white and 1 yellow) and two boart fragments (c. $8 \%$; grey/black).

The Type IIa white diamonds of Letšeng regularly fetch high prices with stones in the +10.8 ct size fraction often exceeding US\$20,000/ct. Noteworthy was the US\$58,000/ct achieved for a Letšeng Type IIa white 27.62 ct diamond in the first quarter of 2008 . As the +10.8 ct size fraction makes up c. $75 \%$ of the revenue for the Letšeng Diamond Mine, the contribution by the Type IIa diamonds is clearly substantial.

Table 2. Percentage Type IIa diamonds per diamond size class for Main and Satellite Pipes, Letšeng

\begin{tabular}{|c|c|c|}
\hline Main Pipe $(\mathrm{n}=15924)$ & Diamond Size Class & Satellite Pipe $(\mathrm{n}=6648)$ \\
\hline $31.82 \%$ & $+10.8 \mathrm{cts}$ & $50.54 \%$ \\
\hline $27.78 \%$ & $5-10 \mathrm{cts}$ & $41.23 \%$ \\
\hline $20.09 \%$ & $2-4 \mathrm{cts}$ & $28.84 \%$ \\
\hline $18.15 \%$ & $3-6$ grainer & $20.93 \%$ \\
\hline $18.58 \%$ & $+5-12$ sieve & $25.34 \%$ \\
\hline
\end{tabular}

\section{Conclusion}

Thus it is the combination of the unusual characteristics of the Letšeng diamonds, most notably the abundance of large, high quality Type IIa stones, rather than the grade, which makes these two kimberlite pipes a viable economic mine (Figure 7).

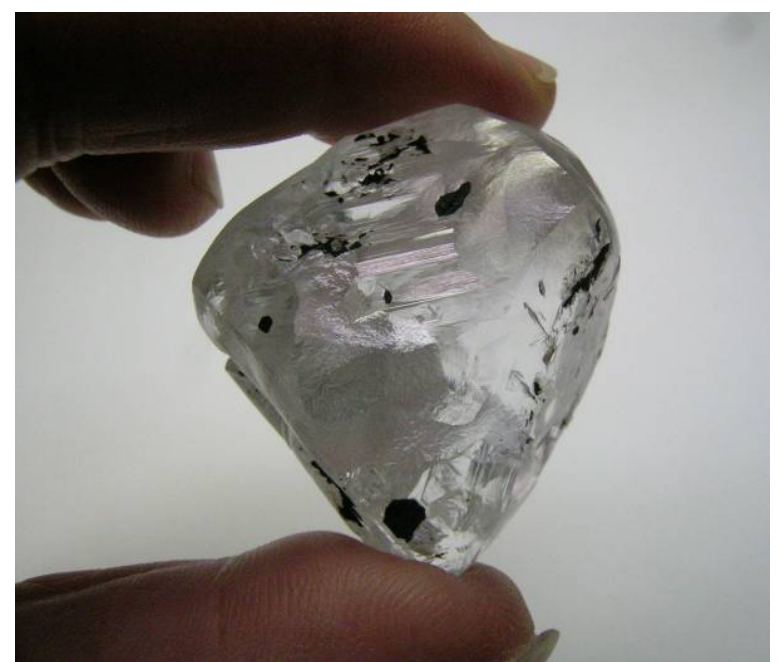

Figure 7. A 215ct Type IIa diamond recovered at Letšeng in January 2007

\section{References}

Bloomer, A.G. and Nixon, P.H., 1973. The geology of the Letšeng-la-Terae kimberlite pipes. In: Nixon, P.H. (Ed.), Lesotho Kimberlites, Lesotho National Development Corporation, Maseru, 20-36.

Harris, J.W., 1973. Observations on the Letšeng-la-Terae diamonds. In: Nixon, P.H. (Ed.), Lesotho Kimberlites, Lesotho National Development Corporation, Maseru, 3738.

McDade, P. and Harris, J.W., 1999. Syngenetic inclusion bearing diamonds from Letseng-la-Terai, Lesotho. In: Gurney, J.J., Gurney, J.L., Pascoe, M.D. and Richardson, S.H. (Eds.), Proceedings of the 7th International Kimberlite Conference Volume 2, Red Roof Designs, Cape Town, 557-565.

McKenna, N., 2004. Physical characteristics and infrared properties of diamonds from the Satellite Pipe at Letsengla-Terai, Lesotho. De Beers Group Exploration, Geoscience Centre, Internal Report No. KR04/0324, Johannesburg, 13pp.

Robinson, D.N., 1979. Surface Textures and other features of diamonds. Unpublished $\mathrm{PhD}$ thesis, University of Cape Town, 221pp.

Whitelock, T.K., Ward, J.D. and Smith, C.B., 2004. Letšeng kimberlite pipes, Lesotho: the highest diamond mine in the world re-opened. Geoscience Africa 2004, Abstract Volume, University of Witwatersrand, Johannesburg, South Africa, 704-706. 